\title{
An Investigation of Presumptive Synergism of Oil Palm Bunch Ash and Sawdust Amendments in Remediation of crude oil Spiked Soil
}

\author{
*11ALBERT, EJIKEME; ANYANWU, DI
}

\author{
Department of Plant Science and Biotechnology, University of Port Harcourt, P. M.B. 5323, Port Harcourt, Nigeria \\ *Corresponding author (Albert, Ejikeme; Email: ejikemealbert@gmail.com)
}

\begin{abstract}
Presumed synergistic effect of combined amendment of crude oil spiked soil with oil palm bunch ash and sawdust was carried out in a laboratory experiment. Two kilogram $\left(2 \mathrm{~kg}\right.$ ) of sandy soil was placed in each of five plastic vessels labeled $T_{\mathbf{A}}, \mathrm{T}_{\mathbf{B}}, \mathrm{T}_{\mathbf{C}}, \mathrm{T}_{\mathbf{D}}$ and $\mathrm{T}_{\mathbf{E}} . \mathrm{T}_{\mathbf{A}}$ was left in its natural state while the others were each polluted with $6.7 \% \mathrm{v} / \mathrm{w}$ of crude oil. $\mathrm{T}_{\mathbf{B}}$ was not given any remediation amendment. $T_{C}$ and $T_{D}$ were each amended with $13.3 \%$ of oil palm bunch ash and sawdust respectively while $\mathrm{T}_{\mathbf{E}}$ was amended with $13.3 \%$ each of oil palm bunch ash and sawdust. The setups were replicated five times and watered twice weekly. Results showed that soil $\mathrm{pH}$ increased from $8.7 \pm 0.04$ to $10.5 \pm 0.06,5.3 \pm 0.01$ to $8.5 \pm 0.04$ and $5.6 \pm 0.18$ to $11.5 \pm 0.15$ for $\mathrm{T}_{\mathbf{C}}, \mathrm{T}_{\mathbf{D}}$ and $\mathrm{T}_{\mathbf{E}}$ respectively. Percentage total petroleum hydrocarbon contents reduced by $65 \%$ for $\mathrm{T}_{\mathbf{C}}, \mathrm{T}_{\mathbf{D}}$ and $52 \%$ for $\mathrm{T}_{\mathbf{E}}$. Total organic carbon increased from $7.6 \pm 0.7$ to $8.5 \pm 0.5 \% \%$, reduced from $4.0 \pm 0.1 \%$ to $3.7 \pm 0.3 \%$ and from $4.1 \pm 0.1 \%$ to $2.2 \pm 1.0 \%$ $\mathrm{T}_{\mathbf{C}}, \mathrm{T}_{\mathbf{D}}$ and $\mathrm{T}_{\mathbf{E}}$ respectively. Total nitrogen increased from $0.66 \pm 0.1$ to $0.69 \pm 0.0 \%$ for $\mathrm{T}_{\mathbf{C}}$, remained nearly the same for $T_{\mathbf{D}}$ and reduced from $0.4 \pm 0.0$ to $0.2 \pm 0.0 \%$ for $T_{E}$ while average phosphorus increased from $0.4 \pm 0.0$ to $23.0 \pm 4.2 \mathrm{mg} / \mathrm{kg}, 0.3 \pm 0.0$ to $1.8 \pm 0.4 \mathrm{mg} / \mathrm{kg}$ and from $0.2 \pm 1.0 \mathrm{mg} / \mathrm{kg}$ to $52.6 \pm 4.6 \mathrm{mg} / \mathrm{kg}$ for $\mathrm{T}_{\mathbf{C}}, \mathrm{T}_{\mathbf{D}}$ and $\mathrm{T}_{\mathbf{E}}$ respectively. Conclusively, combined amendment with oil palm bunch ash and sawdust did not induce synergism in soil total petroleum hydrocarbon content reduction. (C) JASEM
\end{abstract}

http://dx.doi.org/10.4314/jasem.v20i1.9

\section{INTRODUCTION}

The activities of the oil and gas industry in Nigeria's Niger Delta has brought about widespread environmental pollution in the area. The pollutant of concern affecting the environment of the area is crude oil. Some prominent negative effects of petroleum hydrocarbon on the environment is the alteration of soil properties (Kayode et al., 2009; Barua et al., 2011). Studies have shown that soil petroleum hydrocarbon contamination decreases soil moisture content, bulk density, water porosity, water holding capacity, increases soil acidity and decreases phosphorous contents but increases soil total nitrogen content and total organic carbon (Kayode et al., 2009; Barua et al., 2011; Marinescu et al., 2011; Abosede, (2013). Field assessments of crude oil polluted ecosystems by Okoro et al. (2011), Okop and Ekpo (2012) and Oyem and Oyem (2013) reported elevated levels of soil total petroleum hydrocarbon content and total hydrocarbon contents. Studies on the effects of petroleum hydrocarbon on soil or its alteration of soil chemical properties reported negative effects on plants and animals.

The problem of petroleum hydrocarbon environmental pollution in Nigeria's Niger Delta cannot stop now because the oil and gas mining activities still continues. Studies on amendment of petroleum hydrocarbon polluted soil with oil palm bunch material and sawdust reported significant reduction of soil total hydrocarbon content (Amajuoyi and Wemedo, 2015; Tanee and Albert, 2011; Godoy-Faundez et al., 2008).

However, there is dearth of report study on combined use of the materials for application in remediation petroleum hydrocarbon polluted soil. Hence, this present work was undertaken to investigate presumed synergism in combined use of the materials for remediation of petroleum hydrocarbon impacted soil. The findings from this study could widen our knowledge on the environmentally beneficial use of the materials for remediation and mitigation of petroleum hydrocarbon polluted soil. This knowledge could be useful for application by the local people for cleanup of small scale and not very severe cases of petroleum hydrocarbon spill especially as the materials are locally available.

\section{MATERIALS AND METHODS}

This experiment was carried out at Centre for Ecological Studies, University of Port Harcourt. Top 
soil (sandy soil) was collected within $5 \mathrm{~cm}$ depth from a fallow land within the university premises. The soil was air-dried and sieved with $2 \mathrm{~mm}$ mesh. Bonny Light Crude Oil was obtained from Shell Petroleum Development Company of Nigeria while oil palm bunches and sawdust were collected from artisanal palm oil mill and wood sawmill. The oil palm bunches were burnt in a furnace to derive its ash i.e. oil palm bunch ash (OPBA). The chemical analysis of sample oil palm ash was carried out and its profile is as shown in Table 1.

Table 1: Chemical Profile of Oil Palm Fruit Bunch Ash used in this Study

\begin{tabular}{clc}
\hline S/N & Property & Value \\
\hline 1. & $\mathrm{pH}$ & 10.59 \\
2. & Conductivity $(\mu \mathrm{s} / \mathrm{cm})$ & $103,720.00$ \\
3. & Nitrate $(\mathrm{ppm})$ & 107.50 \\
4. & Phosphate $(\mathrm{ppm})$ & 24.60 \\
5. & Total Organic Carbon $(\%)$ & 0.20 \\
6. & Chloride $(\mathrm{mg} / \mathrm{kg})$ & $26,401.90$ \\
7. & Cation exchange capacity $(\mathrm{meq} / 100 \mathrm{~g})$ & 330.70 \\
8. & $\mathrm{Sulphate}(\mathrm{mg} / \mathrm{kg})$ & 110.00 \\
9. & $\mathrm{Na}^{+}(\mathrm{mg} / \mathrm{kg})$ & 5.03 \\
10. & $\mathrm{Ca}^{2+}(\mathrm{mg} / \mathrm{kg})$ & 0.26 \\
11. & $\mathrm{Mg}^{2+}(\mathrm{mg} / \mathrm{kg})$ & 0.48 \\
12. & $\mathrm{Fe}^{2+}(\mathrm{mg} / \mathrm{kg})$ & 6.34 \\
13. & $\mathrm{~K}^{+}(\mathrm{mg} / \mathrm{kg})$ & 324.93 \\
\hline
\end{tabular}

Two kilogram $(2 \mathrm{~kg})$ of the processed soil thoroughly homogenized weighed with digital weighing balance (ohaus scout II SC4010) was randomly placed in each of five (5) plastic buckets (dimensions: $20 \mathrm{~cm}$ height by $18 \mathrm{~cm}$ diameter: $5000 \mathrm{~cm}^{3}$ volume) with five bottom perforations of $5 \mathrm{~mm}$ diameter to avoid waterlogging in the vessels. The buckets of the processed sand were immediately watered with 500 $\mathrm{ml}$ of distilled water to simulate natural condition. Each vessel served as a setup and were labeled $\mathrm{T}_{\mathbf{A}}$, $\mathrm{T}_{\mathbf{B}}, \mathrm{T}_{\mathbf{C}}, \mathrm{T}_{\mathbf{D}}$ and $\mathrm{T}_{\mathbf{E}} \cdot \mathrm{T}_{\mathbf{A}}$ was left without crude oil treatment and so served as double control while $\mathrm{T}_{\mathbf{B}}$, $\mathrm{T}_{\mathbf{C}}, \mathrm{T}_{\mathbf{D}}$ and $\mathrm{T}_{\mathbf{E}}$ were each treated with $6.7 \%(\mathrm{v} / \mathrm{w})$ crude oil and allowed to stand for 24 hours after treatment for the crude oil to properly infiltrate into the soil. $\mathrm{T}_{\mathbf{B}}$ was left so after the crude oil treatment as such, it served as the control while $T_{\mathbf{C}}$ and $T_{D}$ were further treated by thoroughly mixing the crude oil treated soil with $13.3 \%(\mathrm{w} / \mathrm{w})$ oil palm bunch ash (OPBA) and $13.3 \%(\mathrm{w} / \mathrm{w})$ of sawdust respectively. Finally, $\mathrm{T}_{\mathbf{E}}$ was prepared by thoroughly mixing $13.3 \%(w / w)$ each of OPBA and sawdust with its soil. The details of the setups were as shown below.

$\mathrm{T}_{\mathbf{A}}$ - Soil (2 kg): no pollution (double control).

$\mathrm{T}_{\mathbf{B}}$ - Soil $(2 \mathrm{~kg})+$ crude oil $(6.7 \%, \mathrm{v} / \mathrm{w})$ : (polluted-noremediation; control).

$\mathrm{T}_{\mathbf{C}}-$ Soil $(2 \mathrm{~kg})+\operatorname{crude}$ oil $(6.7 \%, \mathrm{v} / \mathrm{w})+$ OPBA $(13.3 \%, \mathrm{w} / \mathrm{w})$.

$\mathrm{T}_{\mathbf{D}}$ - Soil $(2 \mathrm{~kg})+$ crude oil $(6.7 \%, \mathrm{v} / \mathrm{w})+$ sawdust $(33.3 \%, \mathrm{w} / \mathrm{w})$.

$\mathrm{T}_{\mathbf{E}}$ - Soil $(2 \mathrm{~kg})+$ crude oil $(6.7 \%, \mathrm{v} / \mathrm{w})+$ OPBA $(13.3 \%, \mathrm{w} / \mathrm{w})+$ sawdust $(33.3 \%, \mathrm{w} / \mathrm{w})$.
Each setup was replicated five (5) times. The setups were shaded from direct sunlight and rain and watered with $500 \mathrm{ml}$ of distilled water twice weekly.

Soil samples were collected from each setup for chemical properties analyses. First samples were collected 24 hours after treatment with the crude oil but before amendment with any remediation amendment. Subsequent samplings were carried out at 30 days intervals and the experimental setups were allowed for one hundred and fifty (150) days. Soil $\mathrm{pH}$ and conductivity were determined through meter method by means of $\mathrm{pH}$ meter (model: Hanna HI 8314) and conductivity meter (model: HACH Ectestr microprocessor series) using slurry of sample soil and distilled water in the ratio of 1:1 (w/v). The meter electrodes were dipped into the slurry and the $\mathrm{pH}$ and conductivity displayed by the instruments recorded. Soil total petroleum hydrocarbon (TPH) content was determined through gas chromatography/flame ionization detection (GC/FID) method by means of gas chromatography machine (model: HP 5890 series II) using air-dried soil sample after extraction of its total petroleum hydrocarbon content in dichloromethane as extraction solvent. Total organic carbon (TOC) content was determined by titrimetric method (i.e. Walkley-Black technique) while total organic matter was by calculation using the formula of Combs and Nathan (2011). Rate of reduction of soil total petroleum hydrocarbon content was determined by calculation using the method of Ikhajiagbe and Chijioke-Osuji (2014). Soil total nitrogen and phosphorus contents were determined through spectrophotometry (model: HACH DR/890 colorimeter). Carbon/nitrogen ratio was calculated by 
dividing TOC by total nitrogen while cation exchange capacity was determined in two steps: exchangeable acidity by titration method and exchangeable cations ( $\mathrm{Ca}, \mathrm{Mg}, \mathrm{K}$ and $\mathrm{Na}$ ) by means of spectrophotometry with atomic absorption spectrophotometer (model: GBC avanta).

Mean values and standard deviation of replicates were calculated and used as results. The results obtained were presented in composite column charts in which column represents the mean of five replicates and error bar - the standard deviation.

\section{RESULTS AND DISCUSSION}

Petroleum hydrocarbon pollution alters soil physical and chemical properties. However, bioremediation through amendment with some materials has been reported to mitigate the negative effects of the pollution on soil properties. This restores soil properties.

The findings of oil palm bunch ash (OPBA), sawdust and OPBA/sawdust amendments of crude oil polluted soil as remediation treatments is shown in Fig. 1.
There was no change in $\mathrm{pH}$ of $\mathrm{T}_{\mathbf{A}}$ while crude oil pollution reduced soil $\mathrm{pH}$ of $\mathrm{T}_{\mathbf{B}}$ to neutral. Oil palm bunch ash amendment (i.e. $\mathrm{T}_{\mathbf{C}}$ ) turned soil $\mathrm{pH}$ highly alkaline while sawdust amendment (i.e. $\mathrm{T}_{\mathbf{D}}$ ) turned soil slightly alkaline. OPBA/sawdust (i.e. $\mathrm{T}_{\mathbf{E}}$ ) amendment increased soil $\mathrm{pH}$ significantly. The constant $\mathrm{pH}$ of $\mathrm{T}_{\mathbf{A}}$ is understandable because it was not given neither pollution nor remediation treatments while the reduction in $\mathrm{pH}$ of $\mathrm{T}_{\mathbf{B}}$ could have resulted due to the crude oil treatment. The results of $\mathrm{T}_{\mathbf{A}}$ and $\mathrm{T}_{\mathbf{B}}$ contradict the findings of BenkaCoker and Ekundayo (1995); Abii and Nwosu (2009) who reported no significant difference in soil $\mathrm{pH}$ of both crude oil polluted and unpolluted sites in Niger Delta, Nigeria. Amendment with OPBA and mixture of OPBA and sawdust increased the $\mathrm{pH}$ of $\mathrm{T}_{\mathbf{C}}$ and $\mathrm{T}_{\mathbf{E}}$. The increase in soil $\mathrm{pH}$ of the setups were due to the OPBA treatment. This observation corresponds with Albert and Tanee (2013) which studied the potential of OPBA for remediation of crude oil polluted soil. The increase in soil $\mathrm{pH}$ can be attributed to the OPBA amendment as OPBA sample analysis (i.e. Table 1) showed that it was highly alkaline because of its high cation content.

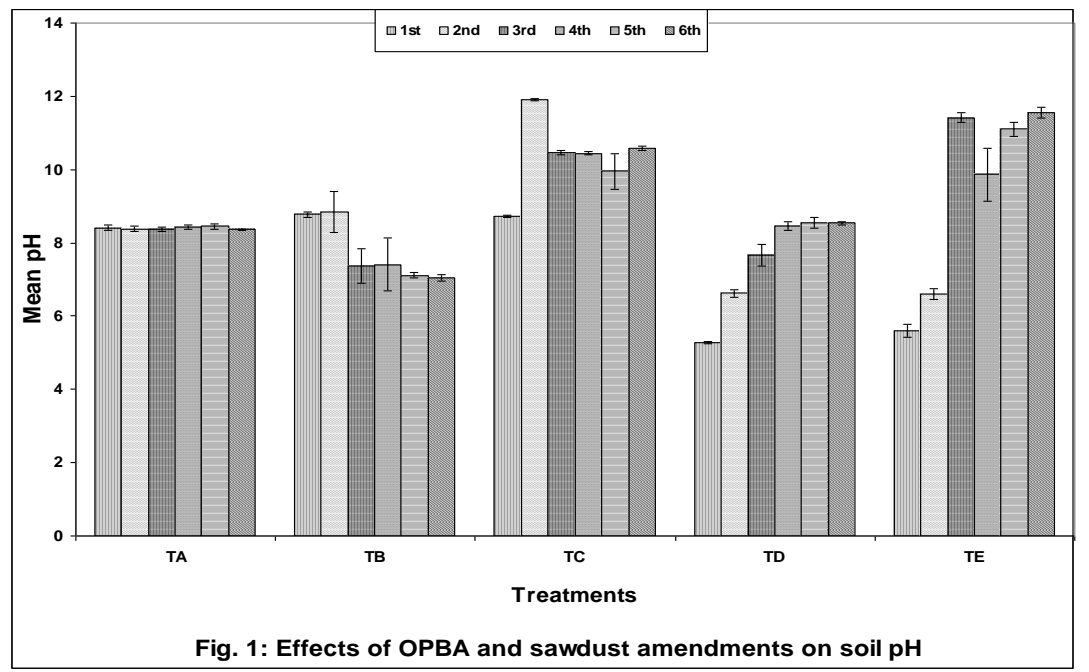

Result represent mean of replicates \pm standard deviation

Soil conductivity result of treatments were summarized in (Fig. 2). The conductivity of $T_{A}, T_{B}$ and $T_{D}$ were significantly low compared with $T_{C}$ and $T_{E}$ (Fig. 2). The high soil conductivity of $T_{C}$ and $T_{E}$ could have resulted from amendment of treatments with OPBA. This is acceptable because sample of
OPBA had high conductivity due to its high cation content (Table 1). Amendment with sawdust improved nutrients and water adsorption potentials of soil via adding negative charges. This may have resulted in the reduction of soil conductivity. 


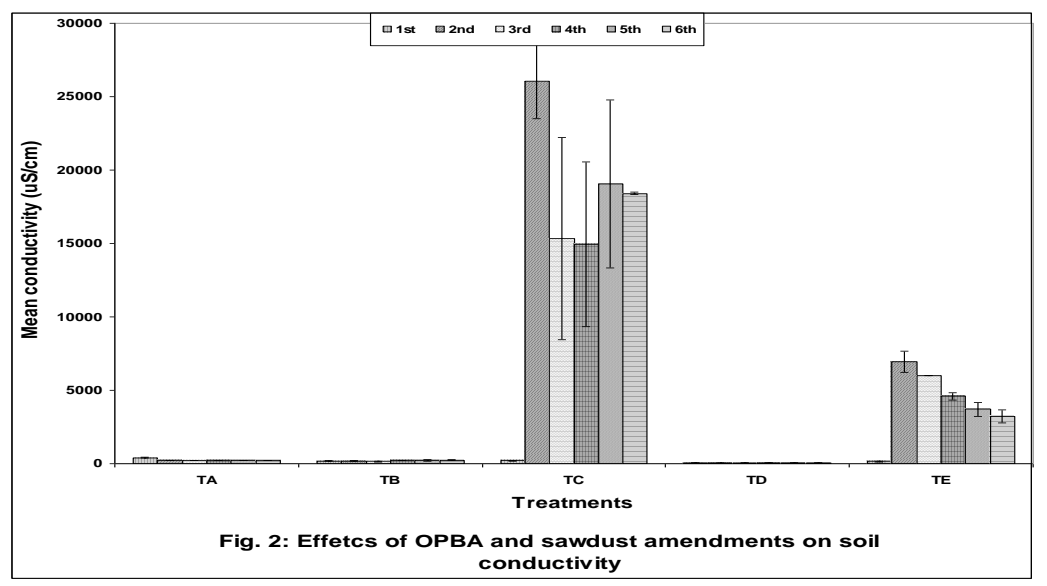

Result represent mean of replicates \pm standard deviation

The effects of OPBA, sawdust and OPBA/sawdust amendments of crude oil polluted soil on total petroleum hydrocarbon (TPH) contents were shown in Fig. 3. Soil TPH content of $\mathrm{T}_{\mathbf{A}}$ was negligible as it was not treated with crude oil. Thirty percent $(30 \%)$ contaminant content reduction was recorded on $\mathrm{T}_{\mathbf{B}}$. This was understandable due to the fact that no remediation treatment was applied to it. Therefore, the mechanism of contaminant removal applicable to this treatment was limited to natural attenuation and this is usually slow and significantly low. Sixty five percent $(65 \%)$ total petroleum hydrocarbon content reduction was recorded for both $T_{C}$ and $T_{D}$ respectively. This higher percentage contaminant loss agrees with Onyelucheya et al. (2013); Amajuoyi and Wemedo (2015) which reported similar result as the effect of OPBA amendment on crude oil and diesel oil polluted soils respectively. The observation could have been the result of biostimulation of the OPBA as its characterization by Udoetok (2012) reported high amounts of essential mineral nutrients which are required for metabolism of living organism. Similar high contaminant loss due to sawdust amendments was reported by Boodoosingh et al. (2007); Tanee and Albert (2011); Atagana (2014) from separate studies of the use of sawdust to enhance degradation petroleum hydrocarbon polluted soil. The high contaminant removal by sawdust was explained by Boodoosingh et al. (2007) to result from the fact that sawdust provided alternate carbon source for indigenous oil degrading microorganisms. Therefore, amendment with this material could have stimulated the degradation of the contaminant by indigenous microbes of the soil which led to the high percentage contaminant loss. However, combined treatment with OPBA and sawdust produced $52 \%$ contaminant loss. This is a reduction in contaminant loss compared with separate amendments with OPBA and sawdust. This means that there was inhibition of contaminant degradation of the polluted soil in combined amendment with OPBA and sawdust. This is speculated to have resulted from the high alkalinity of the medium due to the impact of OPBA amendment on soil $\mathrm{pH}$. The high alkalinity may have negatively affected the metabolism of the indigenous oil degrading microorganism which are the agents of bioremediation

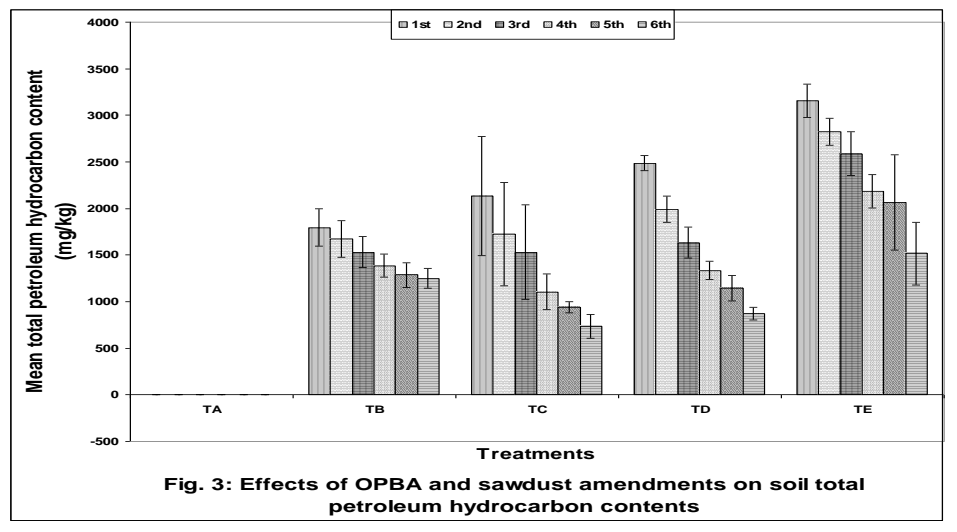

Result represent mean of replicates \pm standard deviation

${ }^{*}{ }^{I}$ ALBERT, EJIKEME; ANYANWU, DI 
Soil total organic carbon (TOC) and total organic matter contents of $T_{\mathbf{B}}$ and $T_{\mathbf{C}}$ were high compared those of $\mathrm{T}_{\mathbf{A}}, \mathrm{T}_{\mathbf{D}}$ and $\mathrm{T}_{\mathbf{E}}$ (Figs. 4 and 5). The low TOC/TOM of $\mathrm{T}_{\mathrm{A}}$ can be explained by the fact that the setup was not treated with the pollutant. However, high TOC result of $T_{B}$ and $T_{C}$ agrees the observation of Amajuoyi and Wemedo (2015) and could have resulted from pollution of $\mathrm{T}_{\mathbf{B}}$ with crude oil coupled with no remediation treatment given to it while OPBA amendment of $\mathrm{T}_{\mathbf{C}}$ could account for its high TOC content. This explanation is supported by the findings of Udoetok (2012) which reported high TOC from characterization of OPBA. Sawdust amendment of the polluted soil as remediation treatment reduced soil TOC/TOM. This result contradicts the findings of Obasi et al. (2013). According to Obasi et al. (2013), addition of organic carbon/matter sources such as sawdust can stimulate microbial activity. It therefore can be speculated that such stimulated microbial activity may have taken place in $T_{\mathbf{D}}$ and $T_{\mathbf{E}}$ leading to the observed low total organic carbon and matter obtained in this study.

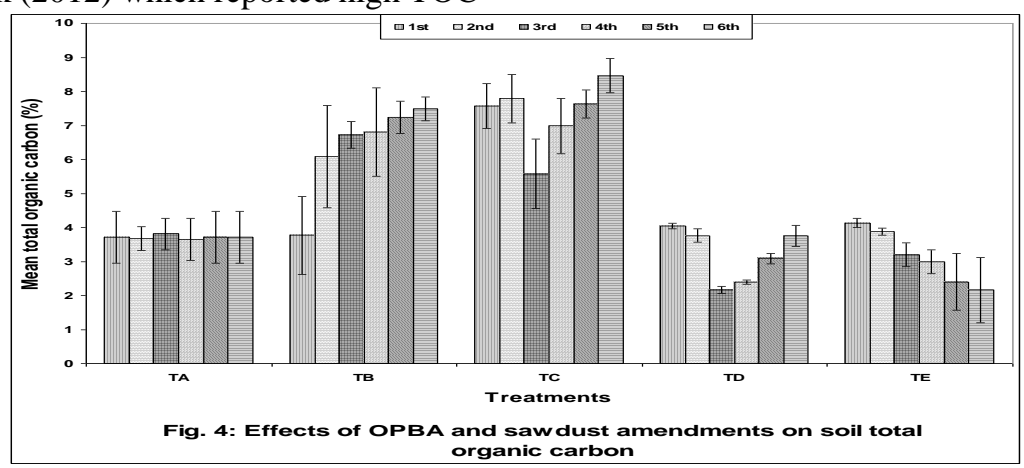

Result represent mean of replicates \pm standard deviation

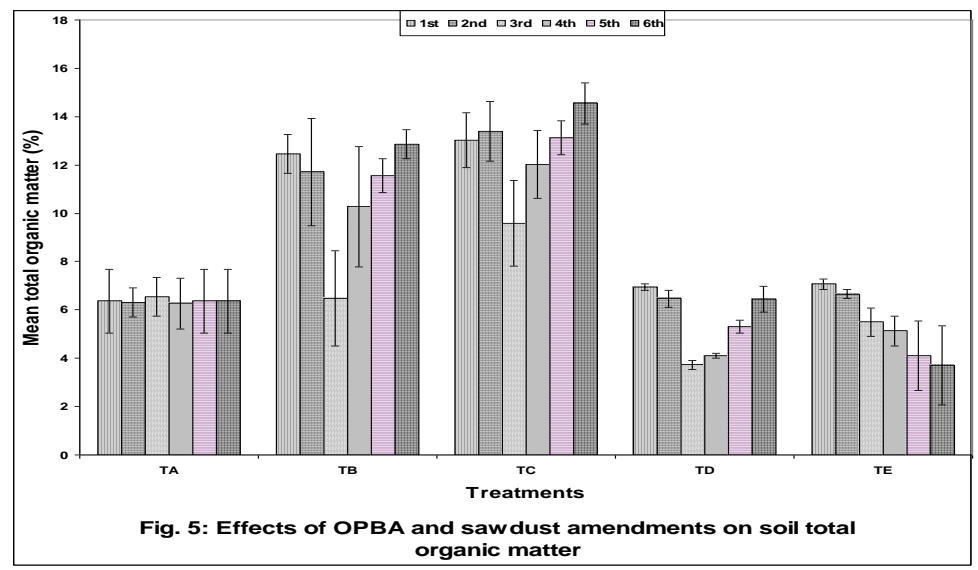

Result represent mean of replicates \pm standard deviation

Rate of reduction of total petroleum hydrocarbon as influenced by the different pollution remediation amendments is illustrated in Fig 6. Rate of reduction of total petroleum hydrocarbon was least in $T_{\mathbf{B}}$ but higher in $T_{C}$ and $T_{D}$. The observation on $T_{B}$ agrees with the studies of Amajuoyi and Wemedo (2015). That could have been because of no remediation amendment was added to stimulate biodegradation of the pollutant while the high rate of TPH reductions of $T_{\mathbf{C}}$ and $T_{\mathbf{D}}$ could have been due to the different amendments of the polluted soil. Combination of OPBA and sawdust (i.e. $\mathrm{T}_{\mathbf{E}}$ ) did not increase rate of TPH reduction 


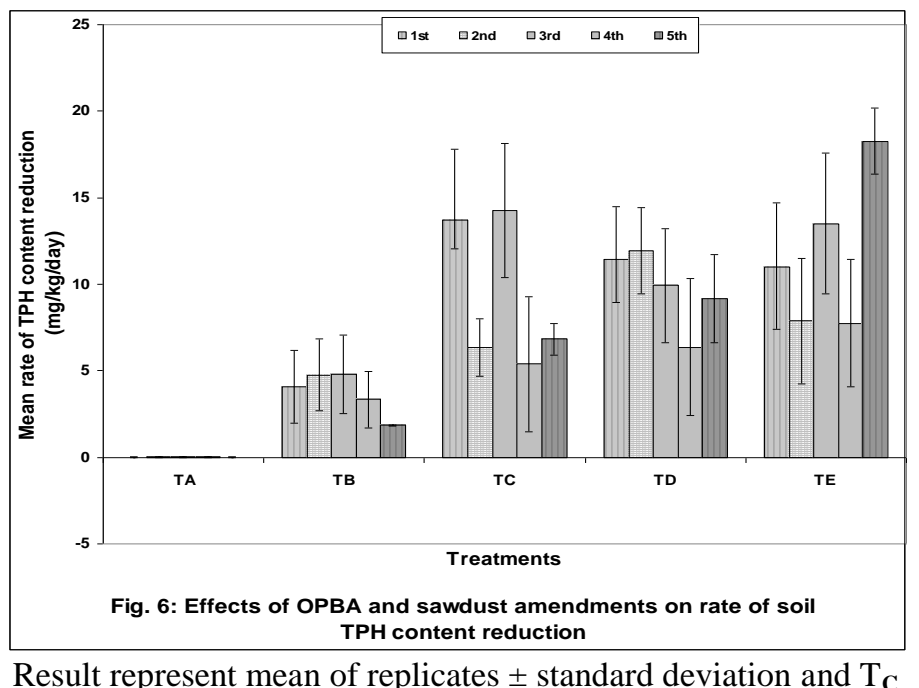

Fig. 7 showed the effect of OPBA, sawdust and OPBA/sawdust amendments on soil total nitrogen contents of the setups. There were significant difference between soil total nitrogen contents of treatments. Soil total nitrogen contents of $T_{A}$ was lower than that of $T_{B}$ which can be explained to be because $T_{B}$ was treated with crude oil and $T_{A}$ was not. $\mathrm{T}_{\mathrm{C}}$ had higher total nitrogen contents compared with $T_{D}$. High soil total nitrogen of $T_{B}$ and $T_{C}$ tally with the findings of Eneje and Ebotomei (2011); Albert and Tanee (2013) which reported high soil nitrogen content in crude oil polluted and OPBA amended soils respectively. The observation on $\mathrm{T}_{\mathbf{B}}$ suggests that the crude oil is the source of the nutrient while that of $\mathrm{T}_{\mathbf{C}}$ was due to OPBA amendments. This is justified by Table 1. OPBA/sawdust (i.e. $\mathrm{T}_{\mathbf{E}}$ ) produced similar result as sawdust only amendment. Therefore $T_{\mathbf{E}}$ had no synergistic effect on treatment nitrogen content.

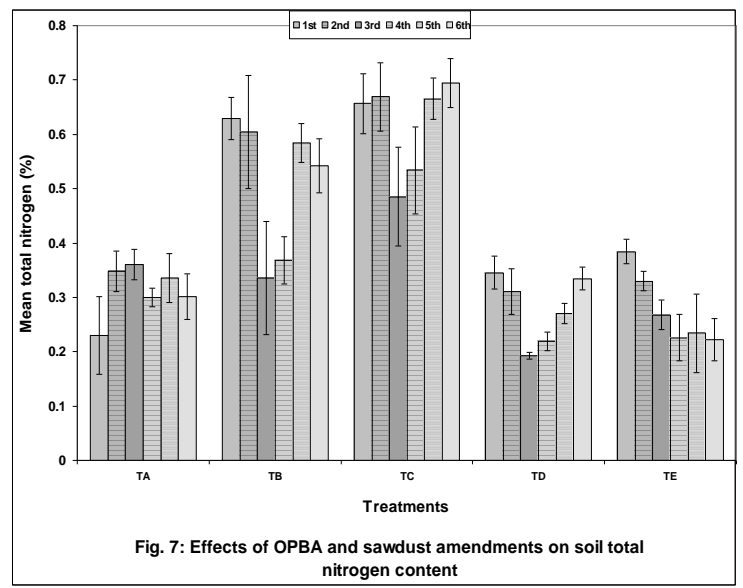

Result represent mean of replicates \pm standard deviation
Soil phosphorus content of $\mathrm{T}_{A}, \mathrm{~T}_{\mathbf{B}}$ and $\mathrm{T}_{\mathbf{D}}$ were significantly low but high in $\mathrm{T}_{\mathbf{C}}$ and $\mathrm{T}_{\mathbf{E}}$ (Fig. 8). Crude oil treatment slightly increased average phosphorus content of $T_{\mathbf{B}}$ but significantly increased the average soil phosphorus content of $\mathrm{T}_{\mathbf{C}}$. This can simply be attributed to the OPBA amendment of the treatment. However, soil average phosphorus of $T_{\mathbf{D}}$ was slightly increased. This result implies that amendment with sawdust slightly increased soil average phosphorus content. OPBA/sawdust amendment i.e. $T_{\mathbf{E}}$ significantly increased soil average phosphorus.

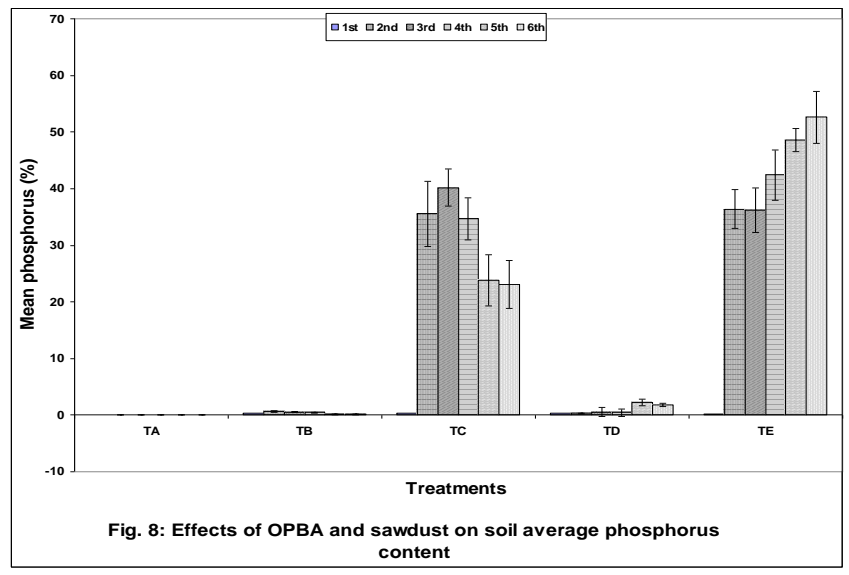

Result represent mean of replicates \pm standard deviation

The effect of OPBA and sawdust on soil $\mathrm{C} / \mathrm{N}$ ratios was summarized in Fig. 9. There were no significant difference between carbon $\mathrm{C} / \mathrm{N}$ ratios of treatments (Fig. 9). C/N ratio was slightly high at the 1 st and 4th samplings for $T_{A}$ and $T_{B}$ respectively. OPBA/sawdust amendment (i.e. $\mathrm{T}_{\mathbf{E}}$ ) had no significant effect on $\mathrm{C} / \mathrm{N}$ 
ratio compared with their respective separate amendments $\mathrm{T}_{\mathbf{C}}$ and $\mathrm{T}_{\mathbf{D}}$.

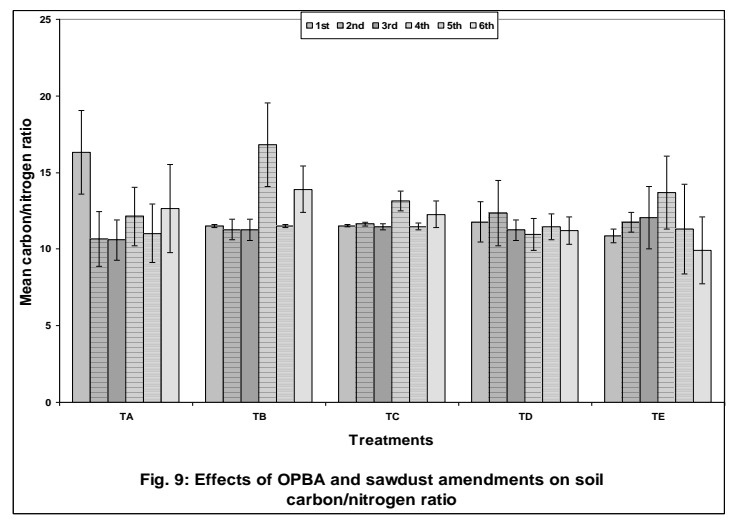

Result represent mean of replicates \pm standard deviation

Soil cation exchange capacity, CEC result as influenced by OPBA, sawdust and OPBA/sawdust amendments was as shown in Fig. 10. Soil cation exchange capacity of $\mathrm{T}_{\mathbf{A}}$ was nearly the same at all sampling times. This was almost the case for $T_{\mathbf{B}}$ except at the $3^{\text {rd }}$ sampling. Amendment with OPBA significantly increased CEC of $\mathrm{T}_{\mathbf{C}}$ at the $5^{\text {th }}$ and $6^{\text {th }}$ sampling times (Fig. 10). The observed increase in CEC of $T_{\mathbf{C}}$ could be the influence of the OPBA amendment as sample OPBA used in this study showed high cation content (Table 1). However, CEC was reduced in $T_{\mathbf{D}}$ as amendment with sawdust improves nutrients and water adsorption potentials of soil via adding negative charges. CEC of $T_{\mathbf{E}}$ increased with sampling time to its maximum at the $5^{\text {th }}$ and $6^{\text {th }}$ sampling. OPBA/sawdust amendment moderated soil CEC of $\mathrm{T}_{\mathbf{E}}$ compared with $\mathrm{T}_{\mathbf{C}}$.

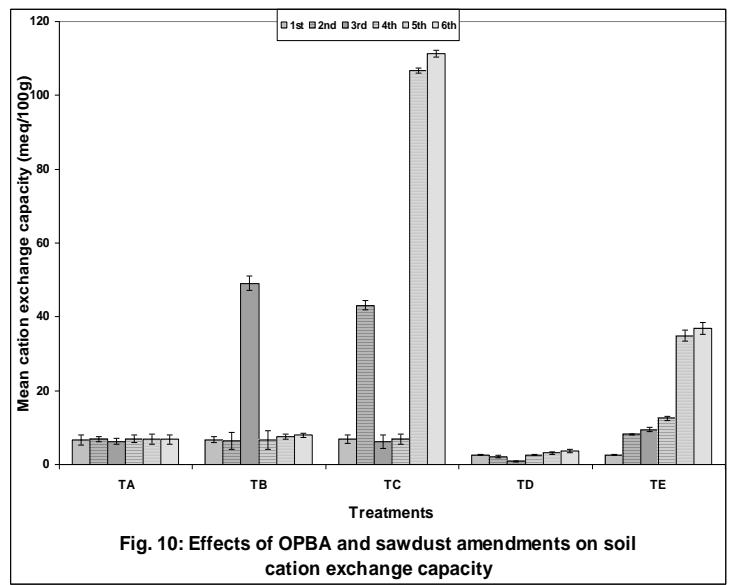

Result represent mean of replicates \pm standard deviation
Conclusion: Results obtained from the investigation of synergism of crude oil spiked soil by oil palm bunch ash, sawdust, OPBA/sawdust amendments has shown that there was no synergism in soil total petroleum hydrocarbon content reduction. This was justified by the lower percentage soil total petroleum hydrocarbon content loss as observed in OPBA/sawdust amendment compared with each of the separate single amendments with OPBA and sawdust.

\section{REFERENCES}

Abii, T. A. and Nwosu, P. C. (2009). The effect of oil spillage on the soil of Eleme in Rivers State of the Niger-Delta area of Nigeria. Research Journal of Environmental Sciences, 3(3): 316 320.

Abosede, E. E. (2013). Effect of Crude Oil Pollution on some Soil Physical Properties. IOSR J. of Agric. \& Vet. Sc., 6(3): 14 - 17.

Albert, E. and Tanee, F. B. G. (2013). Potential of oil palm empty fruit bunch ash for remediation of crude oil polluted soil. Scientia Africana, 12(2):68 - 76 .

Amajuoyi, C. A. and Wemedo, S. A. (2015). Effect of Oil Palm Bunch Ash (Elaeis guineensis) on the Bioremediation of Diesel Oil Polluted Soil. American Journal of Microbiology and Biotechnology, 2(2):6 - 14.

Atagana, H. I. (2014). Managing physicochemical parameters in compost systems to enhance degradation of petroleum wastes from a sludge dam. African Journal of Biotechnology, 13(7):857 - 865.

Barua, D, Buragohain, J., and Sarma, S. K. (2011). Certain physico-chemical changes in the soil brought about by contamination of crude oil in two oil fields of Assam, NE India. European Journal of Experimental Biology, 1 (3):154-161.

Benka-Coker, M. O. and Ekundayo, J. A. (1995). Effects of an oil spill on soil physico-chemical properties of a spill site in the Niger Delta Area of Nigeria. Environmental Monitoring and Assessment, 36:93 - 104.

Boodoosingh, R., Swan, C., Desmarais, A. M., and Beckles, D. M. (2007). The Effect of Bulking Agent and Initial Contaminant Concentration on the Biodegradation of Total Petroleum Hydrocarbons. Proceedings of the Annual 
International Conference on Soils, Sediments, Water and Energy, 12(23): 219 - 226. Accessed at

http://scholarworks.umass.edu/soilsproceedings/ vol12/iss 1/23 on 20th October, 2015.

Combs, S. M. and Nathan, M. V. (2011). Soil organic matter. In: Brown, J. R., Recommended chemical soil test procedures for the North Central Region. North Central Regional Research Publications No. 221 (Revised).

Eneje, R. C. and Ebomotei, E. (2011). Effect of crude oil pollution on soil physicochemical properties and germination percent of Amaranthus hybridus. Nig. J. Soil \& Env. Res., 9: 97 - 103.

Godoy-Faundez, A., Antizar-Ladislao, B. ReyesBozo, L. Camaano, A. and Saez-Navarrete, C. (2008). Bioremediation of contaminated mixtures of desert mining soil and sawdust with fuel oil by aerated in-vessel composting in the Atacama Region (Chile). Journal of Hazardous Materials, 151(2-3):649-657.

Ikhajiagbe, B. and Chijioke-Osuji, C. C. (2014). Natural Attenuation of Soil after Contamination with Petroleum Products. Current Advances in Plant Sciences Research, 1(1): 18 - 23.

Kayode, J., Oyedeji, A.A. and Olowoyo, O. (2009). Evaluation of the Effects of Pollution with Spent Lubricating Oil on the Physical and Chemical Properties of Soil. The Pacific Journal of Science and Technology, 10(1): $387-391$.

Marinescu, M., Toti, M., Tanase, V., Plopeanu, G., Calciu, I. and Marinescu, M. (2011). The Effects of Crude Oil Pollution on Physical and Chemical Characteristics of Soil. Research Journal of Agricultural Science, 43 (3): 125 - 129.
Obasi, N. A., Eze, E., Anyanwu, D. I. and Okorie, U. C. (2013). Effects of organic manure on the physicochemical properties of crude oil polluted soils. African Journal of Biochemistry Research, 6(7): $67-75$.

Okop, I. J. and Ekpo, S. C. (2012). Determination of Total Hydrocarbon Content in Soil after Petroleum Spillage. Proceedings of the World Congress on Engineering 2012 Vol. III, WCE 2012, July 4 - 6, London, U.K.

Okoro, D., Oviasogie, P. O. and Oviasogie, F. E. (2011) Soil quality assessment 33 months after crude oil spillage and clean-up. Chemical Speciation \& Bioavailability, 23:1, 1 - 6.

Onyelucheya, O. E., Osoka, E. C. and Onyelucheya, C. M. (2013). Modelling palm bunch ash enhanced bioremediation of crude-oil polluted soil. International Journal of Science and Engineering Investigatons, 2(13): 8 -12.

Oyem, I. L. R. and Oyem, I. L. (2013). Effects of Crude Oil Spillage on Soil Physico-Chemical Properties in Ugborodo Community. International Journal of Modern Engineering Research, 3(6):3336 - 3342.

Tanee, F. B. G. and Albert, E. (2011). Biostimulation potential of sawdust on soil parameters and cassava (Manihot esculenta; Crantz) yields in crude il polluted tropical soil. Advances in Environmental Biology, 5(5): 938 - 945.

Tanee, F. B. G. and Albert, E. (2011). Biostimulation potential of sawdust on soil parameters and cassava (Manihot esculenta; Crantz) yields in crude oil polluted soil. Advances in Environmental Biology, 5(5):938 - 945.

Udoetok, I. A. (2012). Characterization of ash made from oil palm empty fruit bunches (oefb). Int'l $J$. Environ. Sci., 3(1):518 - 524. 